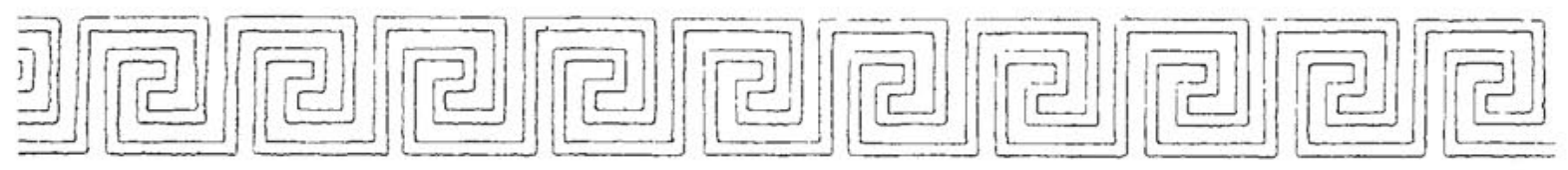

Akademie

derWissenschaften

derDDR

Zentralinstitut

für Alte Geschichte

und Archäologie

Beiträge
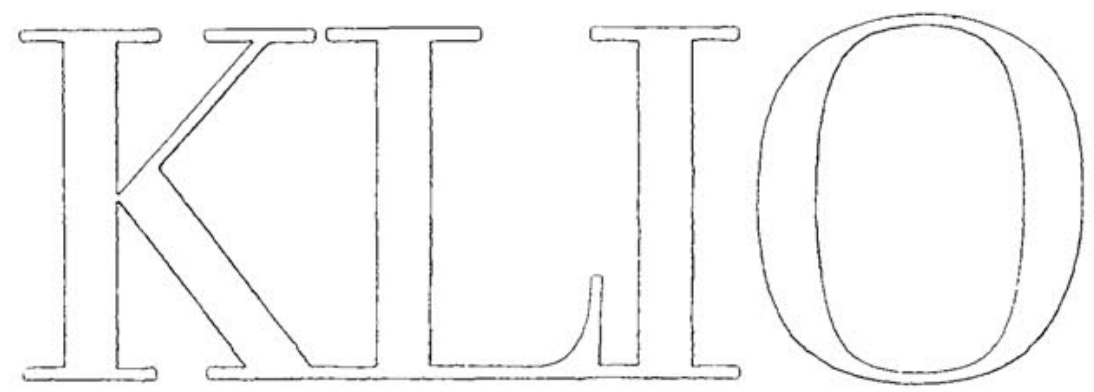

zur

\title{
Alten Geschichte
}

Band $70 \cdot 1988 \cdot$ Heft 2

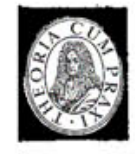

Akademie-Verlag $\cdot$ Berlin

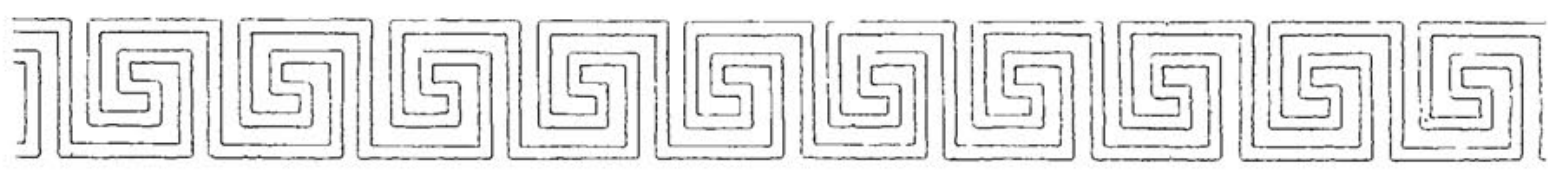

